\title{
Dismantling of hipped roof and restoration of cribbed structure of monastic buildings, churches and temples
}

\author{
Dmitry Zhivotov ${ }^{1, *}$, and Olga Galaktionova ${ }^{1}$ \\ ${ }^{1}$ Deputy Director for restoration of the limited liability Company “AVK Group” (LLC “AVK \\ Group"), Saint Petersburg, Russia
}

\begin{abstract}
The paper is devoted to the problem of adaptation and restoration of monastic structures, churches and temples without complete dismantling of the elements of the main load-bearing structures, using technologies and methods of work that allow delicately and effectively restoring the most important elements of buildings. The progress of work on the restoration of the hipped roof, using the lifting method - lifting the load-bearing part of the cribbed roof structure, is accurately and consistently described in the paper, as well as flexibility and efficiency in choosing a new solution for lifting, taking into account the features of the object identified during the work. The work on raising the roof was carried out during the course of adapting the building to modern use, based on the needs of the Kirillo-Belozersky museum-reserve.
\end{abstract}

\section{Introduction}

Kirillo-Belozersky historical, architectural and art museum-reserve is located in the Kirillov city of Vologda region.

The history of its creation dates back to 1924, and at first it was a branch (department) of the Cherepovets district provincial Museum. In 1926, it was transferred to the Main Science Department of People's Commissariat for Education and became an independent Museum, and in 1929 the first permanent exhibition was opened [13].

In the days of the Great Patriotic War the Museum was not closed. Although the number of employees in it has sharply decreased. In the autumn of 1941, the Museum took care of the exhibits evacuated from Novgorod. In 1942, when the front line approached the borders of the Vologda region, the Museum began to prepare for a partial evacuation. In December 1941, the permanent exhibition of the Museum had to be closed, as in its place, in the vast refectory, a workshop for repairing aircraft engines was placed; a number of buildings of the Museum were occupied by military units. Repair and restoration work resumed in the Museum in 1943. The government Commission for the registration and protection of monuments, which visited Kirillov city in the same year, made recommendations for improving the protection of monuments in wartime. The War greatly

* Corresponding author: d.zhivotov@mail.ru 
affected the restoration process. It was only by 1948 that the Museum was able to catch up and fully develop the funds granted for this purpose.

In 1953, a group of architects from the Central research and restoration workshops at the Academy of Architecture of the USSR arrived in Kirillov, which outlined priority tasks for the rescue of monuments which were in poor conditions, and laid the foundation for research and restoration work. In 1957, the Kirillovsky restoration division of the Vologda scientific and restoration production workshop was established. The division's forces began gradually to output the monuments of the Kirillo-Belozersky Monastery and Ferapontov Monastery from the emergency condition. For a long time, the Moscow architect Sergey Sergeevich Podyapolsky managed this process [11]. In February 1969, the Regulations on the Museum-reserve were approved. The new status of the Museum has led to a significant expansion. By government decision, in addition to the monuments of the KirilloBelozersky Monastery, the Museum was assigned with the architectural ensembles of the Ferapontov and Goritsky monasteries in order to study, protect and monitor the progress of restoration work. The same document provided for a large complex of works on the monuments and around them: the creation of security zones, measures to improve the accomplishment of Kirillov city, arrangement of asphalt roads, putting in order the shoreline of lake Siverskoe, the withdrawal of bases and warehouses from the territories adjacent to the Museum. And despite the fact that only part of this program was completed, the creation of the Museum-reserve had a beneficial effect on the development of the city and the Kirillovsky district [5].

\section{Materials and methods}

The paper presents a solution to the problems of engineering and technical cycleidentification of the technical condition of cultural monuments, the causes and factors of destructive processes, for projecting and implementing technical measures to ensure the long-term preservation of its structures. The conditions and condition of structures are studied. The study of structures is usually done by examining the current state. Further, we proposed and implemented the development of technological recommendations, the choice of restoration materials, taking into account the causes of destruction. Design studies of restoration and restoration of unique cultural heritage structures were developed and implemented.

\section{Results and discussion}

\subsection{The part 1}

Continuing its activities for the preservation of cultural heritage in December 2017, the work unfolds on a vast section of the monastery walls of the New city: fence made of long poles, where Residential cells with closets were located, and after the prison, four towers: Moscow, Vologda, Belozerskaya, Kosaya [12].

The authors of the project were the Federal State Unitary Enterprise "Tsentral'nyye Nauchno-Restavratsionnyye Proyektnyye Masterskiye" in the person of S. B. Kulikov and A.S. Kulikov.

The company "AVK Group" begins the works on the "Kosaya tower". Object (Fig. 1) located in the middle of the northern fortress wall of the city between Ferapontova (Moscow) and Bolshaya Merezhnaya (Belozerskaya) corner towers. 


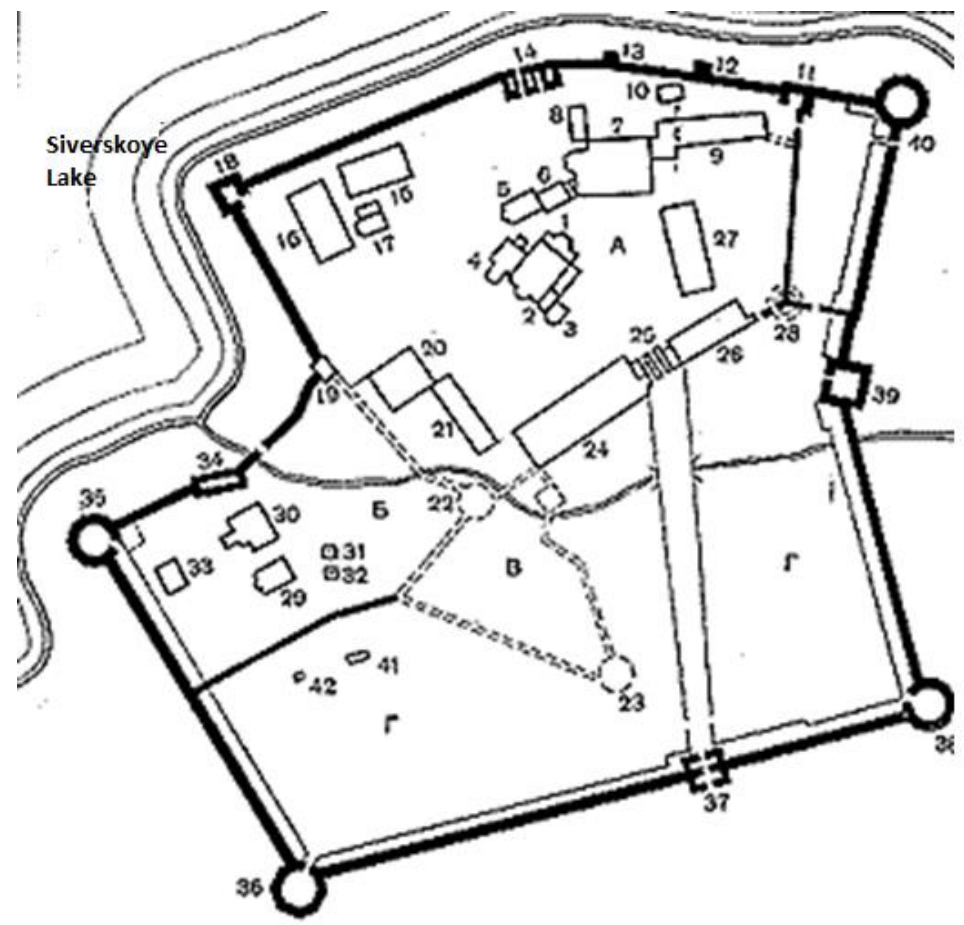

Fig. 1. Schematic plan of the Kirillo-Belozersky monastery: A-Bolshoy Uspensky monastery; BIvanovsky convent; C-Ostrog; D-Novy Gorod. 1-Uspensky Cathedral; 2 - Church of Vladimir; 3 Church of Epiphany; 4 - Church of Cyril; 5 - Church of the Archangel Gabriel; 6 - bell tower; 7 - Church of the Introduction and refectory; 8 - cellarer's house; 9 - cookhouse; 10 - cook cells; 11-Merezhennaya tower; 12 - Pvarskaya tower; 13 - Hlebnaya tower; 14 - Water gate with gate temple of the Preobrazheniya; 15 - Spiritual school (cells); 16 - Large hospital chamber; 17 Euthymius Church; 18 - Svitochnaya tower; 19-fishing tent; 20 - monastic archive (cells); 21 priestly cells; 22 - Kruglaya tower; 23 - prison tower; 24 - monastic cells; 25 - the Holy gate with the gate Church of Ioann Lestvichnik; 26 - treasury; 27-archimandrite cells; 28-Granovitaya tower; 29 - Church of Ioann Predtechi; 30 - refectory Church of St. Sergius of Radonezh; 31 canopy over the cross, standing over the original cell of Cyril; 32 - canopy over the wooden chapel of Cyril; 33 - small hospital chamber; 34 - Kotelnaya tower; 35 - Kuznechnaya tower; 36 Vologda tower; 37-Kazan tower; 38 - Ferapontova (Moscow) tower; 39 - Kosaya tower; 40Bolshaya Merezhennaya (Belozerskaya) tower; 41 - Church of the sacrament from the village of Borodavy; 42-mill from the village of Gorki.

Fence made of long poles, coming from these towers diverge at the Kosaya tower at an obtuse angle, while the tower almost all its volume protrudes beyond the line of the fortress walls. The Kosaya tower is the second drive-through gate tower of the New city. However, the passage gate openings are located on the adjacent walls, south and west. Thus, the passage "under the tower" was carried out at an angle, it was "kosoy", hence the name of the tower [9]. 
a)

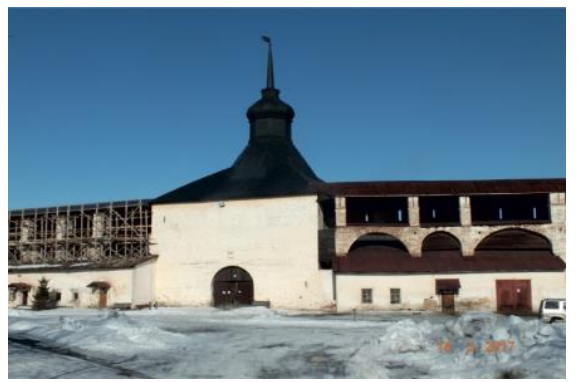

b)

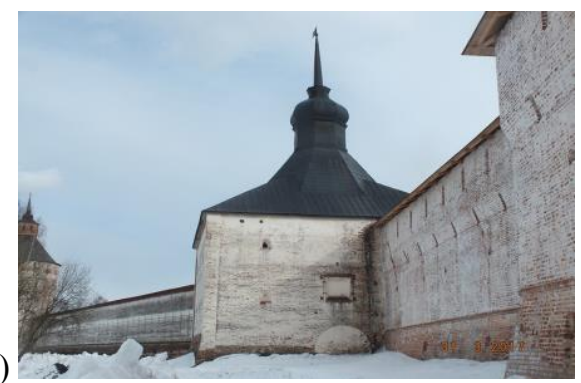

Fig. 2. Kosaya tower. The author of the photos is Galaktionova O. S.: a) - west facade; b) - south facade.

The tower is an almost regular square of walls in plan, cut by two large openings: in the center of the southern wall and in the southern part of the western wall (at the time of restoration, it was closed). A squat monolithic four-sided volume is covered by a hipped roof of complex shape: an octagonal hipped roof is embedded in the lower four-sided cap, completed with a faceted drum, a figured head and a slender spire with a slotted ensign [10].

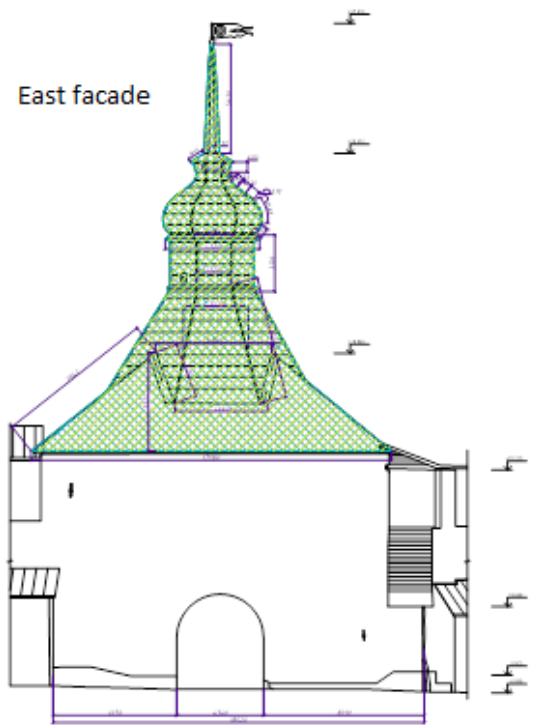
view from the top

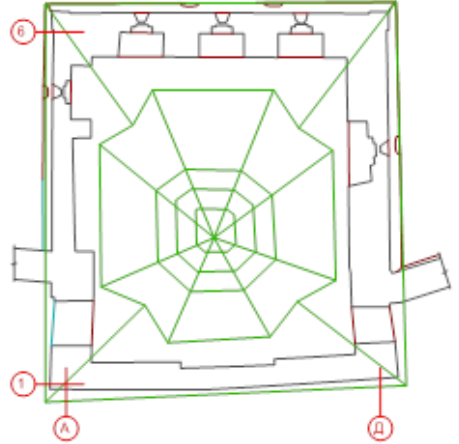

Fig. 3. The east facade and the view from the top. The author of the drawings Galaktionova O. S.

The roof is covered with copper sheets on a solid crate. The existing height of the tower to the spire is $23 \mathrm{~m}$. The shaped roof with a spire belongs to the end of the XVIII - early XIX centuries. The wooden truss system is strengthened, supporting the structure of the hipped roof, metal trusses [4]. The roof structure is based on a hipped log cabin [1].

Repair, restoration and engineering works were carried out for the monument in the 1970s [2]. The most difficult works were carried out to strengthen the structure of the hipped roof. On the first floor, after removing the upper parts of the masonry of the walls, the trusses which supported structure of the hipped roof were installed (project of engineer I. S. Makolov). On the second floor with the help of trusses, by jacking, it was managed to replace the rotten crowns of the log cabin of the hipped roof (project of engineer G. N. 
Rovinsky). In addition, the masonry of the basement of the tower was removed with the restoration of the loopholes.

The condition of the roof before the start of work is shown in Fig. 4.

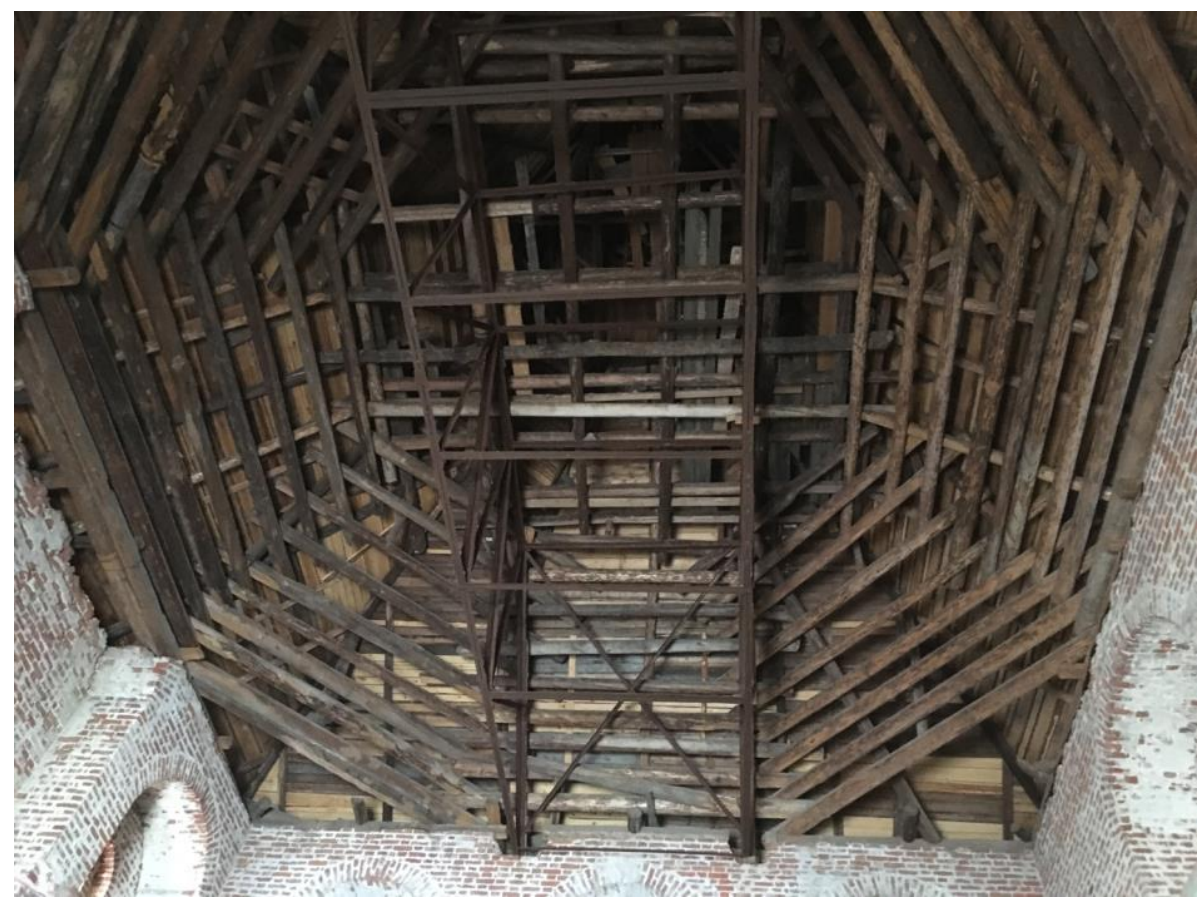

Fig. 4. A cribbed structure of hipped roof and a supporting metal truss installed in the 1970s. The author of the photos Galaktionova O. S.

The metal roof covering was replaced with copper in 2000 .

\subsection{The part 2}

At the moment of the beginning of work in the building there was a transformer substation, intended for removal. There are also longitudinal shrunken cracks of wood, local areas of prosthetics of elements of the truss structure. There is no antiseptic protection of the wooden truss system. Surface corrosion damage of metal structures of the truss is expressed. Drainage from the roof is not organized, which leads to active soaking of the walls, especially in places where fence made of long poles is adjacent. The abovementioned problems became one of the reasons for the work.

The condition of the wall structures is shown in Fig. 5. 
a)

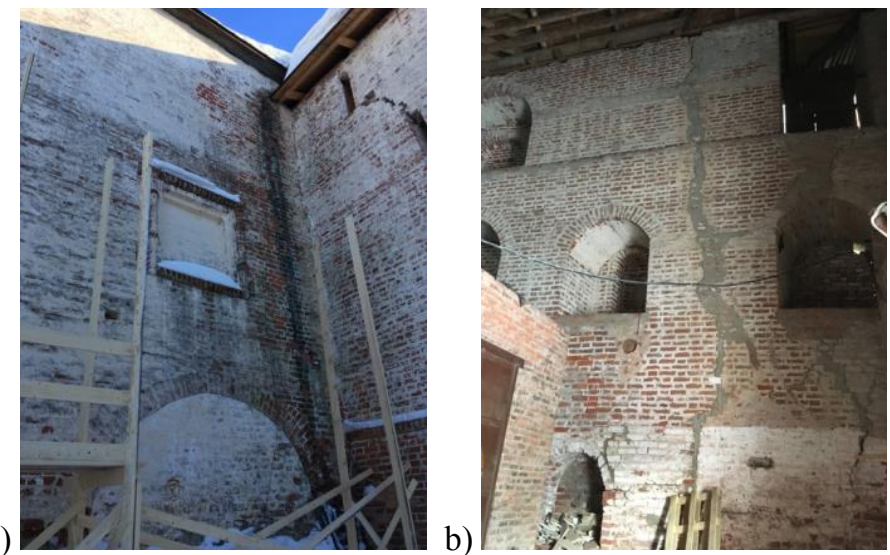

c)

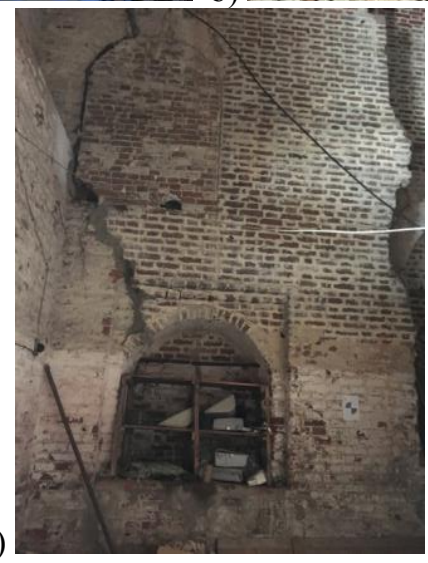

Fig. 5. The interior of the tower. The author of the photos Galaktionova O. S.: a) - unorganized drainage of water from the adjacent roof; b), c) - Kosaya tower interiors: cracks and destruction of brickwork.

The project for adaptation and restoration was supposed to build a restaurant in the volume of the Kosaya tower, which is functionally very necessary and corresponds to the developed general concept of the development of the Museum-reserve.

In order to implement the design solutions and according to the developed project of work production, the Contractor, "AVK Group" LLC, needs to build a new transformer substation outside the monastery, to switch and dismantle the existing one. After dismantling the substation, install a new separately operating structural system on the principle of "mezzanine" with the restoration of brick walls of facades and interiors and further lifting of the existing hipped roof and bulbous roof completion.

Conditionally, the restoration of the "Kosaya tower" object can be divided into three stages:

- restoration of facades and interiors, strengthening of walls and foundations for "lifting" of the roof, "lifting";

- construction of a new 2CTS (complex transformer substation) and dismantling of the existing one;

- construction of reinforced concrete structures.

The first and last stages should be discussed in detail. The second, no less interesting, has little to do with the restoration industry and this experience is not very applicable, but it also deserves a separate conversation. 


\subsection{The part 3. "First stage"}

Until 2017, the walls of the tower did not undergo restoration interventions, except for the strengthening of the roof in 1970. Facades of the tower are actually devoid of ornate decoration, except for a rectangular icon case located on the western facade above the closed arched gate opening, and a miniature niche-icon case in the center of the southern facade. The masonry in the basement of the tower is designed to expand the volume, which gives it special stability. The lower masonry is a one meter high and is made according to the construction of buttresses [8].

The interior of the Kosaya tower in its modern state is peculiar. Its rather impressive interior space is devoid of both planned and vertical partitions and opens into an unshielded hipped roof. Among the original elements in the interior, a significant role is played by large arched niches, in which (through a different number of ledges) loopholes are placed. It is interesting to note that the ledges in the masonry for flooring in the 2nd tier are arranged on the south and north walls of the tower, and in the 3rd on the east and west [6].

The roof structure is based on a hipped log cabin, folded by "vrezh" (nit tight) variant, but with elements of the truss structure. The ancient parts of the tower stand on boulder foundations. The walls are made of a larger brick size of $310 \times 165 \times 90(300 \times 160 \times 85)$, on a lime mortar with grout seam in the system of Russian (Gothic) masonry. The walls are whitewashed on the outside, and the inside of the tower is left in brick. It is known that the tower was almost 2 meters higher, as evidenced by the preserved the arch parts located on the north and south walls (Fig. 6), but during the Soviet period it burned, as a result of which the roof and part of the walls collapsed inside the volume [3].

a)

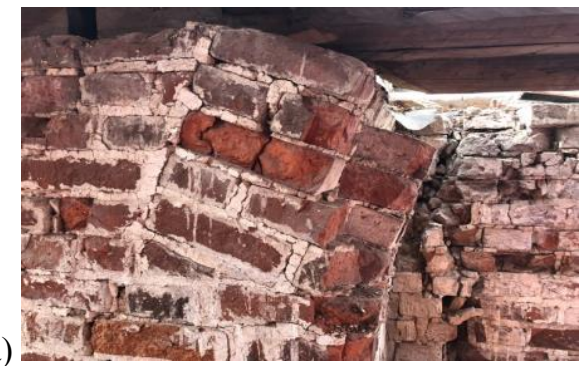

b)

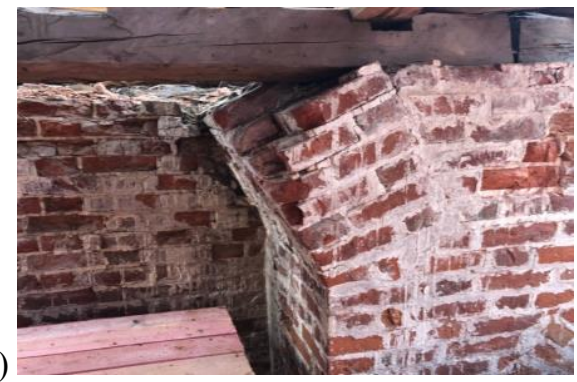

Fig. 6. The surviving parts of the arches of the arched openings. The author of the photographs is Zhivotov D. A.

Especially these data led the authors of the design decision to raise the roof by 2 meters, but not with the reconstruction of the volume of bricks, but the reproduction of the lost volume of logs with the arrangement of a log house. It was supposed to be about 7 crowns, with a diameter from 280 to $350 \mathrm{~mm}$. "Roof lifting" itself was supposed to be done according to the principle worked out in the "Kizhi" reserve: vertically directed trusses were arranged, movable consoles were attached to them, which were set in motion by the jacks. Such trusses and consoles were supposed to be 8 pieces, 2 pieces per wall. The trusses themselves were fastened through studs and mortgages to the historic walls, while the consoles held up the wall plates. To stabilize the crib and bulb, it was supposed to encircle the maximum number of logs by means of compresses made of planks, to create a single unchangeable system, first of all strengthening the wall plate and the first crib logs.

However, in the process of production of works was revealed to the new circumstances that have radically changed the whole process of doing work.

First, the construction of a new 2CTS and the dismantling of the existing one made it much more difficult to conduct work inside the object. The energy-saving company banned 
any wet processes and work near the substation less than 2 meters. This meant that the construction of monolithic floors was postponed until the dismantling of $2 \mathrm{CTS}$.

It becomes logical to perform work on strengthening the foundations by core drilling and cementing the completed wells, which is what the Contractor begins. Catastrophically huge volumes of cementing mortar are poured into wells in the boulder masonry. On average, the well took more than 350 liters, and sometimes all 600 .

After strengthening the foundations by "AVK Group" LLC, the Contractor, starts installing non-inventory scaffolding inside and outside, for access to the roof and performing restoration work on the walls. If the restoration of the brickwork of the walls is carried out in the normal mode: clearing is underway, biocidal treatment, repositioning of cracks, injection, removal and sealing of cracks, then a trial opening of the south-western corner of the roof opens a completely new picture.

a)

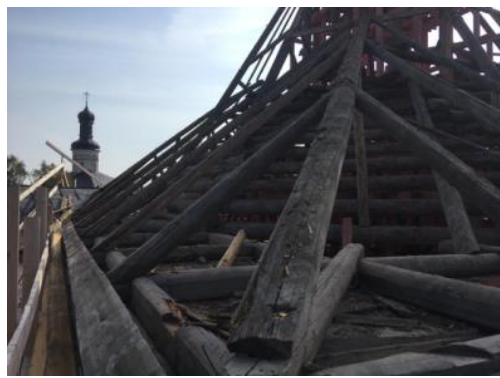

b)

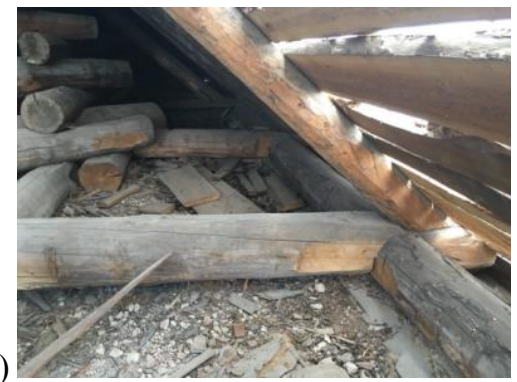

c)

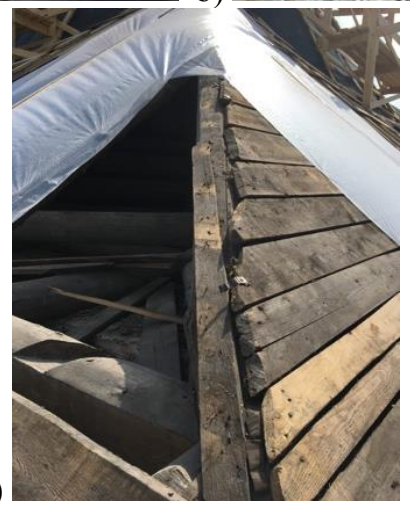

Fig. 7. Condition of the roof. The author of the photographs is Zhivotov D. A.: a) - the place where the cribbed structure is leaning on the walls; b) - existing and identified double wall plate; c) condition of the crate.

The circumstances forcing to reconsider the principle of further work are revealed:

- the presence of a double wall plate, which is the main reason for the inability to climb according to the developed design scheme;

- cribbed structure and wall plate made with cuts;

- cribbed structure lies through the supports on the metal truss;

- the individual elements of the crib have been strengthened by duplication with the fixing through the bracket and wire;

- weakened brick walls of the object in the upper part, destroyed parts of the former arches (Fig. 6).

In the journal of author's supervision from 28.09.2018, the architect A. S. Kulikov made a note about the following:

- lifting works of the "upper hipped roof and roof completion" have been stopped;

- until 07.10.2018, it is planned to issue a "decision on the method of lifting"; 
- it is allowed to conduct work on disassembly of the cribbed structure.

Thus, the principle of lifting the roof by the method of "lifting" becomes the following:

1. Completely removed copper coating.

2. The crate of the four-sided and octagonal hipped roof is dismantled, the crate on the faceted drum and the shaped head with the spire remains.

3. All elements of the truss structure are marked: truss boards, crib, supports (Fig. 8).
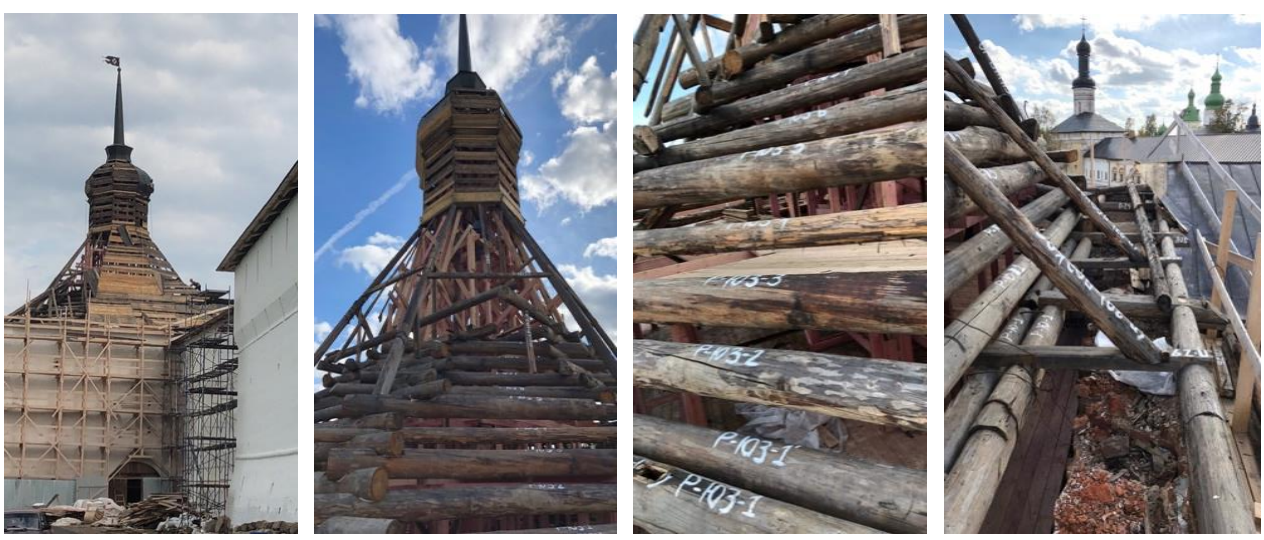

Fig. 8. Marking of wooden elements of the roof. The author of the photographs Galaktionova O. S.

4. The marked elements are removed near the object to prepared platforms, where the logs are further examined, cleared, places for prosthetics are identified or the need for complete replacement of the element is determined.

5. In parallel, reinforced scaffolding is being brought to the center of the faceted drum according to the project "Priority and preparatory works for lifting of the roof". Installation of scaffolding takes into account the current 2CTS and the need to hang out the drum and bulb tower (Fig. 9). This decision is based on the calculation of the weight necessary and possible for lifting. Four reinforced racks connected to each other in a rigid structure form a cube or, as it is called, "glass", which rises to the bulb and later will be the main support for lifting.
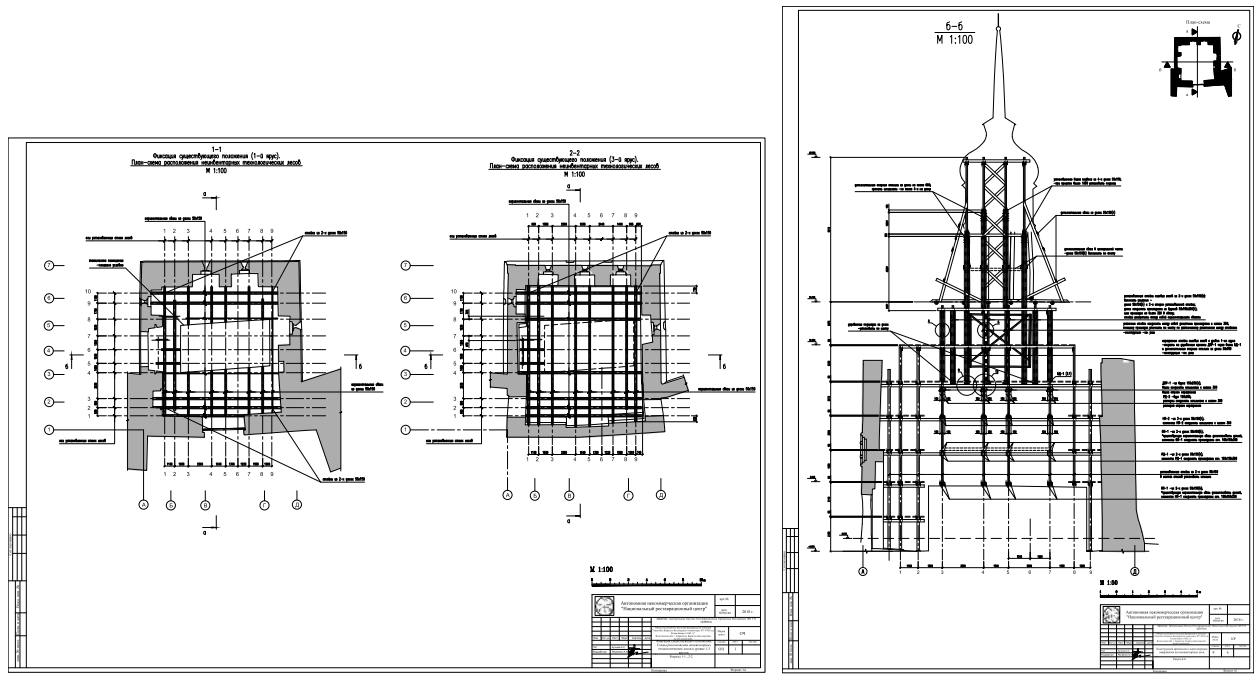

Fig. 9. Design solutions for the installation of non-inventory scaffolding. 
The entire structure of the scaffolding is a pyramid with the tip pointing upwards. From under the drum on each of the four sides radiate two inclined reinforced racks. Each such rack crimps a log. These four logs laid cross - on-cross are the support for the drum racks and are transitional elements in the crib. The entire lifting will be carried out from this place. Only the structure of the drum, bulb and spire will be raised, so the crate on them was not previously disassembled (Fig. 10).

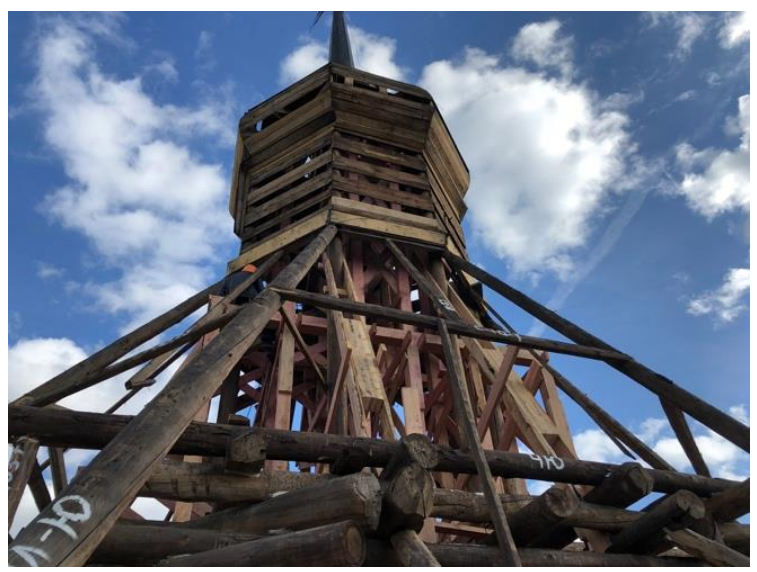

Fig. 10. The structure of the drum, bulb and spire. The author of the photographs is Zhivotov D. A.

Winches are mounted on each side - inside the "glass", additionally, two more winches are installed on the southern and northern sides. In places where four logs rest on the crib, jacks are installed on prepared bases-racks (Fig. 11). As they lifting, the jacks will also rise and provide an additional stabilizing effect.
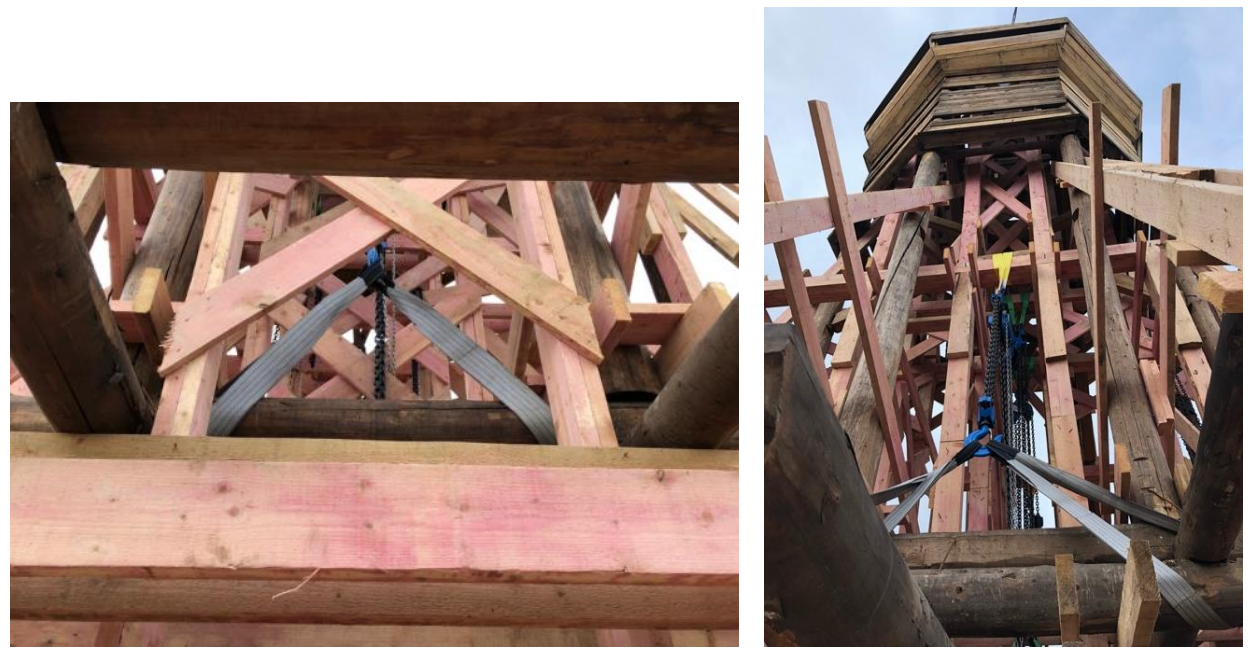

Fig. 11. Arrangement of 8 hoists for lifting the roof of the tower. The author of the photographs is Zhivotov D. A.

After carrying out all the preparatory work, they begin to lift. Eight people start winches and jacks (Fig.11). Light grating, tension of the hoists. Torn off! 


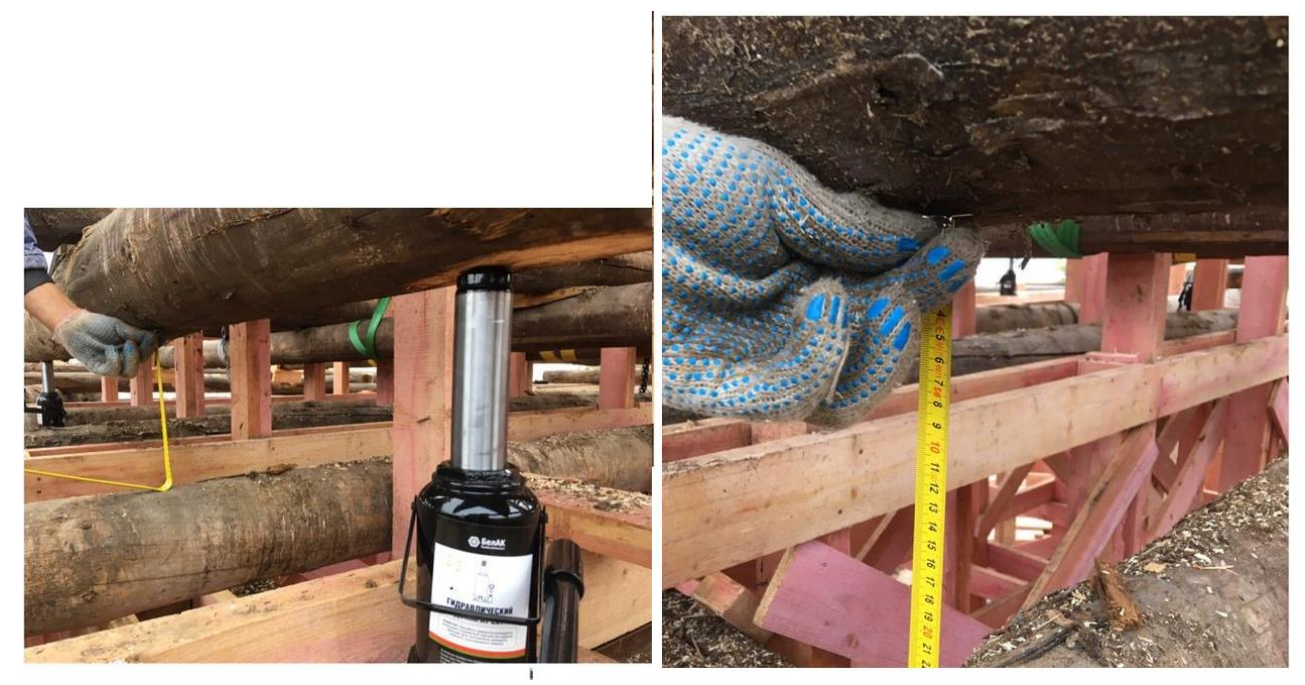

Fig. 12. Arrangement of jack for lifting the roof of the tower. The author of the photographs is Zhivotov D. A.

Now the structure is fully stabilized, completely based on the installed scaffolding and is not connected to the rest of the cribbed structure. The crib begins to be disassembled. All logs are marked and carefully lowered to the ground near the object. As well as truss boards, logs are inspected, cleared, and restored.

The freed upper parts of the walls of the Kosaya tower are examined for deformed bricks, and places for re-laying are identified.

The lifting of the roof structure of the tower was carried out gradually. First, the double wall plate was installed (repeating the wall circumference, preserving the historical curvature).

Further lifting was performed with alternating laying of 2 crowns, lifting the jacks to the height of the next 2 crowns, and so up to a height of 2 meters $=7$ crowns. A calibrated hewn log measuring 300-350 mm was used (Fig. 13).

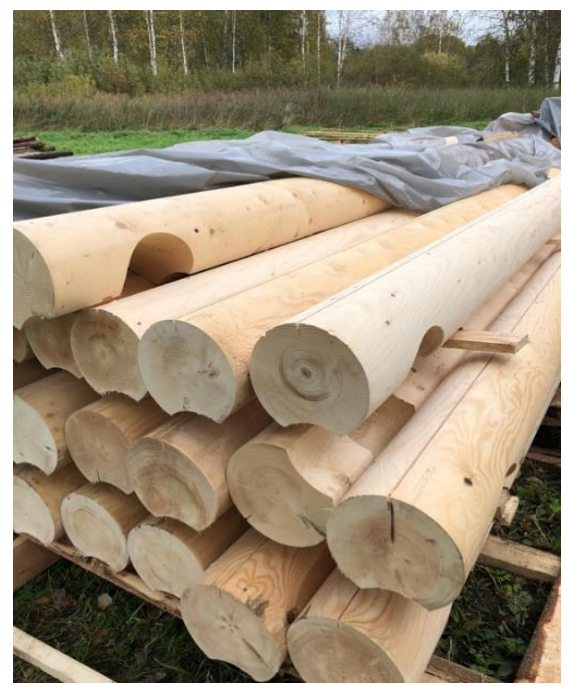

Fig. 13. Calibrated log for a new log house. The author of the photographs is Zhivotov D. A. 
After gaining the necessary design height, the overlying part of the roof was delicately lowered onto the newly created wall, fixed by means of a connection arrangement "in a bowl”.

a)

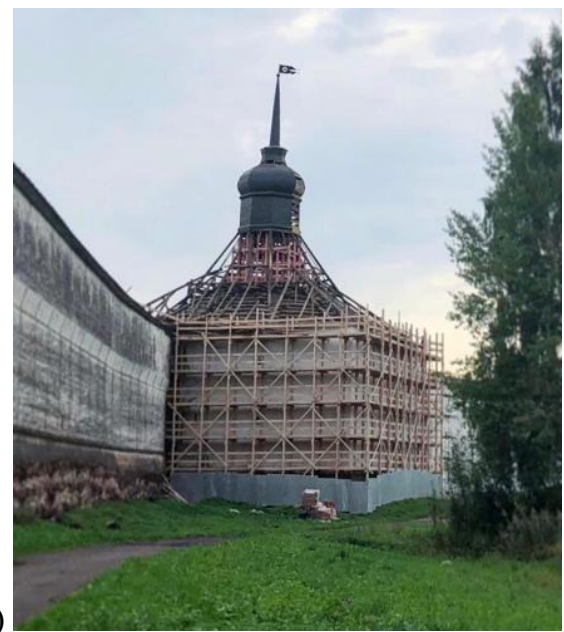

b)

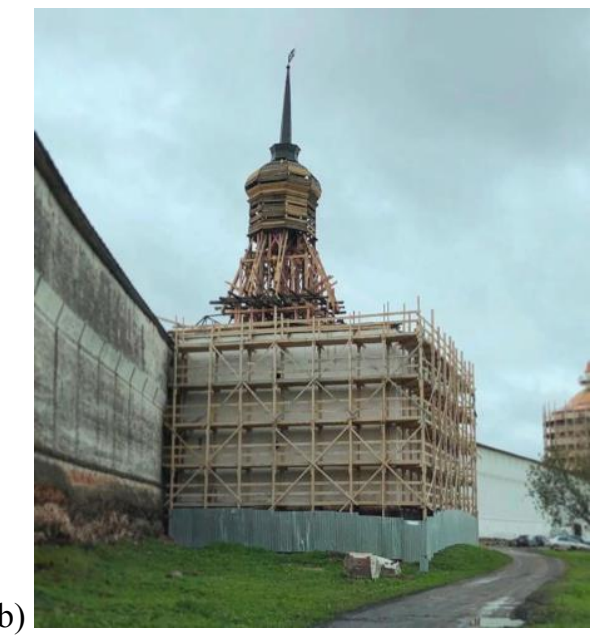

Fig. 14. a) - dismantling of the crate, b) - disassembly of the crib. The author of the photographs Galaktionova O. S.

Restored log with "crib" in accordance with the marking drawings is collecting again. (Fig. 15).

a)

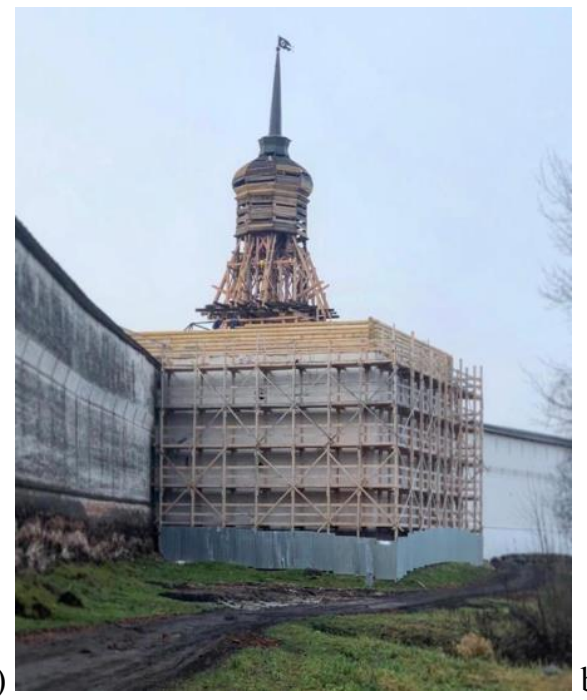

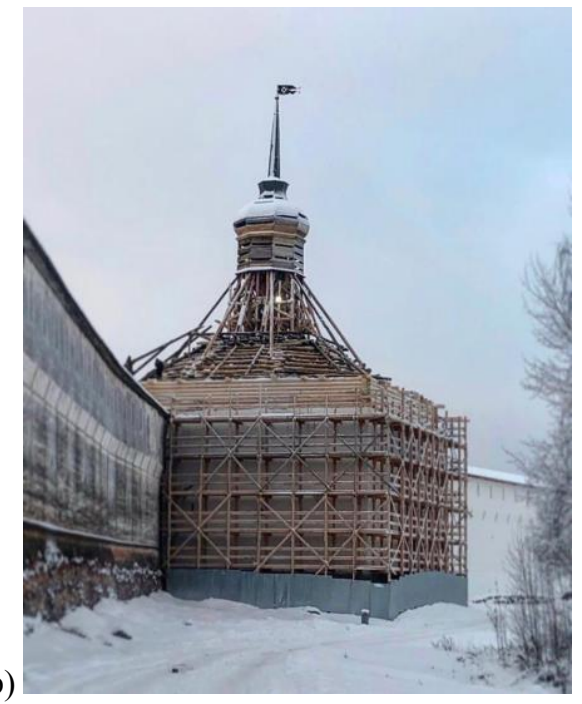

b)

Fig. 15. a) - hanging out the tower, building a log house, b) - assembling the crib and truss boards. The author of the photographs Galaktionova O. S.

Truss boards are set (Fig. 15). 
a)

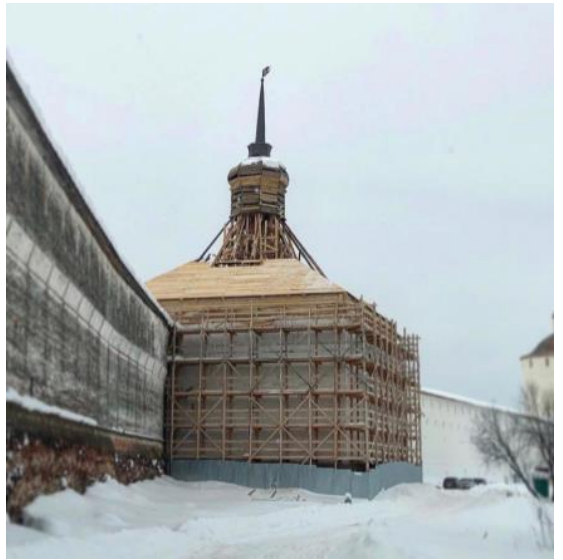

Fig. 16. a) - arrangement of the crate, b) - replacement of the crate of bulb and drum. The author of the photographs Galaktionova O. S.

Arrangement of the crate is carried out.

Installation of hard galvanized steel.

a)

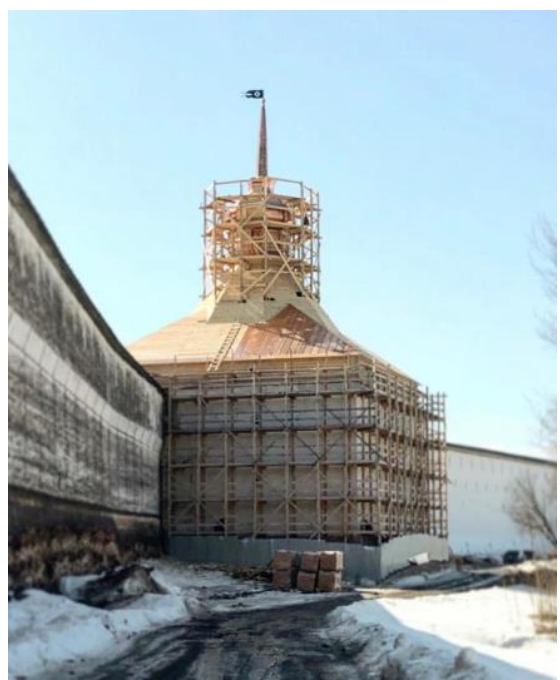

b)

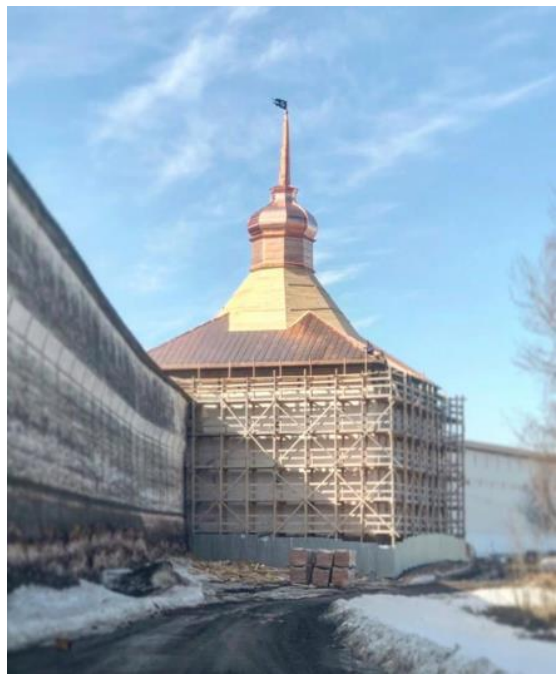

Fig. 17. a) - copper coating of the bulb and drum, b) - copper coating of the main volume. The author of the photographs Galaktionova O. S.

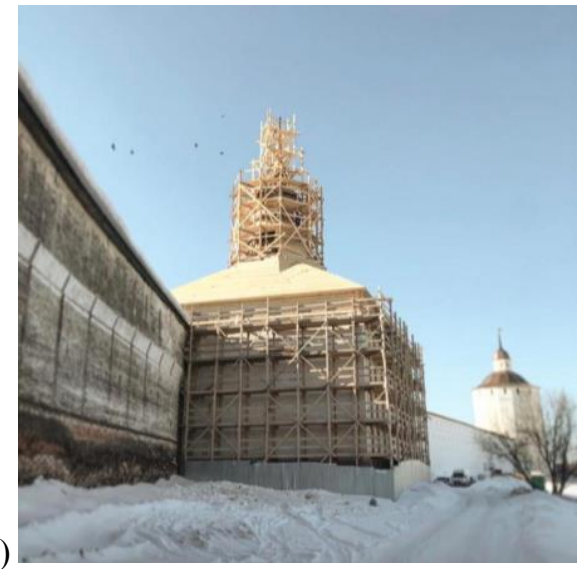


a)

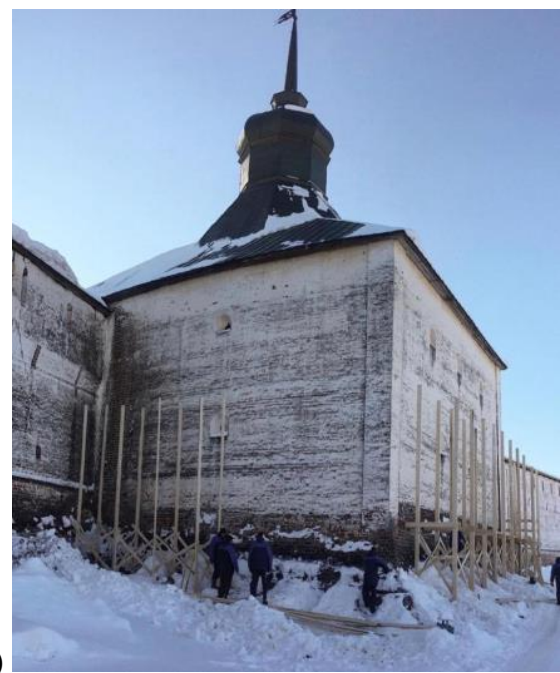

b)

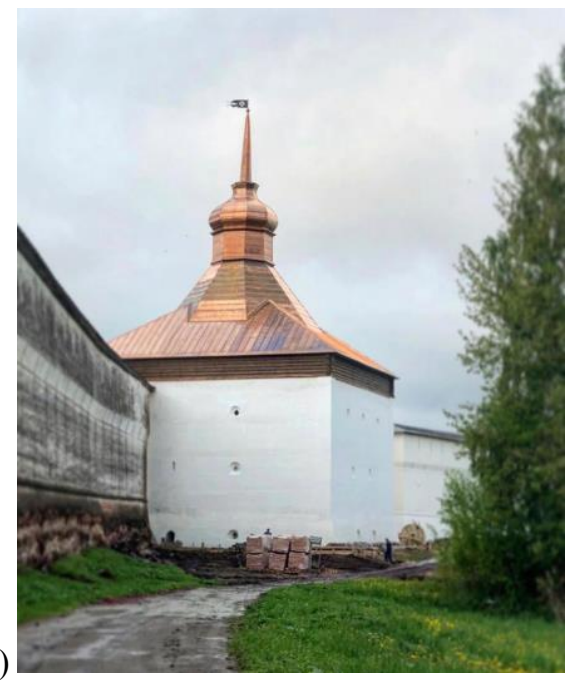

Fig. 18. a) - Kosaya tower BEFORE the execution of the works, b) - Kosaya tower AFTER the execution of the works. The author of the photographs Galaktionova O. S.

\section{Conclusions}

These works once again confirm that successfully applied experience on one object may be completely impossible to perform on another:

1. The joint work of architects, engineers and carpenters allowed us to find the optimal solution in a short time, taking into account the identified features.

2. The interest of all parties to the State contract, the supervision of regulatory authorities, the flexibility of the project authors and the skill of carpentry restorers made it possible to complete the roof lifting with minimal implementation into the structure, avoid unnecessary risks, and preserve all line geometries.

3. Timely identification of features, compromise in decision-making, quick response of both the customer and the contractor, and author's supervision are very important in the process of work production. Taking into account the presence of a transformer substation and occur in the process difficulties, additional and unforeseen work, which goes beyond the terms dictated by the law, the contractor doesn't refuse to perform work, and offers solutions and, after receiving all approvals, getting started. An example of such cooperation was the performance of works on "roof lifting" at the object of cultural significance of federal significance "Ensemble of the Kirillo-Belozersky monastery, XV-XVII century. The Kosaya tower (1662)".

\section{References}

1. G.G. Antipin, Fortress of the Kirillo-Belozersky monastery (Kirillov, 1934)

2. G. Bocharov, V. Vygolov, Vologda. Kirillov. Ferapontovo. Belozersk (Moscow, 1979)

3. V.V. Danilov, Architecture of Leningrad, No. 2 (1939)

4. I.N. Zabek, Collection of research and materials, archive of Historical red Army Museum, 1, L.-M. (1940)

5. G.O. Ivanova, I.A. Smirnov, Local History almanac "Kirillov 1"

6. A.N. Kirpichnikov, I.N. Khlopin, The Great Tsar's fortress (Leningrad, 1972) 
7. N.K. Nikolsky, Kirillo-Belozersky monastery and its structure until the second quarter of the XVII century (SPb., 1910)

8. A.N. Kirpichnikov, I.N. Khlopin, Materials and research on archaeology USSR, No. 77, Moscow (1958)

9. N.K. Nikolsky, Kirillo-Belozersky monastery and its structure until the second quarter of the XVII century (SPb., 1910)

10. P.P. Soikin, Orthodox Russian monasteries: a complete illustrated description of Orthodox Russian monasteries in the Russian Empire and on mount Athos, 126-128, 712, Voskresenje, SPb. (1994)

11. Moscow encyclopedia, 1. Faces of Moscow. Book 3. M-R-M: "Moscow encyclopedias" (2010)

12. https://www.mkrf.ru/press/news/v_bashnyakh_kirillo_belozerskogo_monastyrya_sozd any_18_yarusov_vystavochnykh_prostranstv/

13. http://www.kirmuseum.ru/info/ 